\title{
Expression of Concern for "Hydrogen Bond Directed Photocatalytic Hydrodefluorination: Overcoming Electronic Control"
}

Mohammad B. Khaled, Roukaya K. El Mokadem, and Jimmie D. Weaver III*

J. Am. Chem. Soc. 2017, 139 (37), 13092-13101, DOI: 10.1021/jacs.7b06847

Cite This: https://dx.doi.org/10.1021/jacs.0c02795

Read Online

ACCESS

山lll Metrics \& More

回国 Article Recommendations

$\Delta \mathrm{s}$ of April 8, 2020, the authors have issued an Expression A of Concern to alert readers that some of the spectra in the Supporting Information may have been digitally modified. An investigation is currently underway, and the status of this Article will be updated following completion of this investigation. 